(2) Open Access Full Text Article

\title{
Intratesticular Human Adipose-Derived Stem Cell (hADSC) Transplantation Decreased Oxidative Stress in Testicular Torsion Model of Wistar Rat
}

This article was published in the following Dove Press journal: Research and Reports in Urology

\section{Safendra Siregar \\ Bambang Sasongko Noegroho \\ Ricky Adriansjah \\ Akhmad Mustafa (D) \\ Zola Wijayanti (ID}

Department of Urology, Faculty of Medicine Universitas Padjadjaran, Hasan Sadikin General Hospital, Banding, Indonesia
Correspondence: Safendra Siregar; Bambang Sasongko Noegroho Tel +628II227I80; +628IIII 5058 Email safendra.sir@yahoo.co.id; basanoe@yahoo.com
Introduction: Testicular torsion is a sudden rotation of the testis towards its axis, which causes the twisting of the spermatic cord. Post-detorsion reperfusion will cause inflammation and trigger oxidative stress, which generates reactive oxygen species (ROS). Malondialdehyde (MDA) is an organic compound formed from ROS frequently used as an oxidative stress biomarker during ischemia and ischemia-reperfusion injury. In some organs, stem cell administration on the damaged organ is essential in preventing cellular damage and death. This study aimed to learn about the effect of hADSC administration on an ischemiareperfusion injury.

Material and Methods: A total of 22 Wistar rats divided into 5 groups, two groups each consist of 5 male Wistar rats with testicular torsion model without hADSC therapy (group I), while 2 other groups consist of 5 rats with testicular torsion model were given $1.0 \times 10^{6}$ cells intratesticular hADSC injection 30 minutes after testicular detorsion (group II). Both groups were euthanized at 1 and 4 weeks of observation. The last group consists of 2 rats without any treatment or model (negative control group). Following euthanasia, testicular tissue was harvested for MDA expression measurement using ELISA and histopathological examination. Statistical analysis using an one way ANOVA was done with SPSS version 21.0.

Results: The result of MDA examination using the ELISA method has shown a concentration difference between group I (control) and group II (hADSC treatment). Testicular MDA concentration in the treatment group was significantly lower on the 1st and 4th week of observation $\left(\mathrm{p}_{2}=0.000, \mathrm{p}_{4}=0.016\right)$. Post hoc analysis showed no statistically different between therapy and healthy group $(\mathrm{p}=0.972)$. On histopathological examination, Johnsen score in the treatment group was significantly higher on the 4th week of observation $(p=0.044)$. Post hoc analysis showed no statistically different between therapy and healthy group $(\mathrm{p}=0.195)$.

Conclusion: Intratesticular hADSC administration can inhibit ROS formation due to ischemia-reperfusion injury in testicular tissue after testicular detorsion in Wistar rats.

Keywords: human adipose-derived stem cell, testicular torsion, malondialdehyde; MDA

\section{Introduction}

Testicular torsion is a urological emergency condition when the vascular pedicle of the testes is rotated or twisted. It causes the occlusion of veins and arteries, which will cause testicular ischemia. Testicular torsion is an emergency condition and should be immediately treated because it can potentially cause infertility and reduced sperm count. ${ }^{1}$ Proper management of testicular torsion is necessary considering the high incidence rate and the impact significance. ${ }^{2}$ The most common 
emergency intervention for testicular torsion is the scrotal exploration, detorsion, and orchidopexy. ${ }^{3}$ Surgery is an essential treatment to restore blood flow in order to prevent further ischemia. ${ }^{3,4}$

Post-detorsion reperfusion is a responsive process to the ischemia. Reperfusion or sudden blood flow after occlusion will cause inflammation and trigger oxidative stress, which produces reactive oxygen species (ROS). ROS generate toxic substances that can damage the deoxyribonucleic acid (DNA), cause lipid peroxidation in the cellular and mitochondrial membrane. ${ }^{4,5}$ Such conditions can cause structural and functional loss of testicular tissue, which leads to the disruption of the spermatogenesis process, thus causing infertility. ${ }^{5-7}$ Malondialdehyde (MDA) is an organic compound formed from ROS with the formula of $\mathrm{CH} 2(\mathrm{CHO}) 2$. Hence, MDA is used as an oxidative stress biomarker during ischemia and ischemia-reperfusion injury.

The most widely quoted quantitative histological scoring system for assessing the extent of impaired spermatogenesis in the testes is the Johnsen score; in at least 100 seminiferous tubules, the sperm maturation rate is assessed between 1 and 10 , according to the most advanced germ cells in the tubule. The Johnsen total score is then determined by dividing the total score by the number of tubules evaluated.

One of the alternatives to reduce the risk of complications of testicular torsion is the resolution of tissue damage. The administration of mesenchymal stem cells (MSC) is one of the probable interventions. Due to its multipotent attribute, the stem cell is able to regenerate tissue. Out of all kinds of stem cells, MSC is known as a potent immunomodulator. In other organs, an MSC has potential therapeutic benefits for cases such as myocardial infarction, stroke, brain injury, and acute liver failure. MSCs consist of various types: MSC originating from bone marrow - that is bone marrow MSCs (BM-MSC), MSC originating from bonederived muscle cells, and MSC originating from adiposederived stem cells (ADSC). The ADSC is the type of MSC that has the most optimal therapeutic cell. The ADSC is a mesenchymal stromal cell that is located in perivascular adipose tissue. $^{8}$ (Figure 1)

Based on the data above, we aim to study the effect of ADSC administration on ischemia-reperfusion injury caused by testicular torsion in the Wistar rat model. The ischemia-reperfusion injury will be measured using the MDA level produced by the process of oxidative stress and Johnsen score to assess histopathological changes.

\section{Materials and Methods}

Human ADSCs Isolation and

\section{Characterization}

Human adipose tissue was obtained from the fat of adult male/female subjected to other surgeries who had agreed to donate his/her fat for research by signing informed consent. The research protocol, including the fat obtainment procedure, was approved by the Research and Ethical Committee of Universitas Airlangga Surabaya. Greater expansions were achieved by seeding harvested cells until passage 3 . Cell characterization and transplantation were made in this distinctive cell batch, obtained from a single solely isolated fat donor. We used ADSC from human adipose tissue due to several reasons: 1) liposuction aspirate as an abundant source of the cells, if we used rat ADSC, obtaining enough adipose tissue for ADSC isolation would require several rats to be sacrificed; and 2) In the future, we aim to use human ADSC in human patients, therefore we started by using human ADSC in rats. Since human ADSC does not express MHC class-II it will not trigger a xenogenic immunologic reaction.

During the isolation and culture procedure, cells vitality was at $83.4 \%$. Flow cytometry assay were used to characterize the isolated cells by using the following markers: CD44 (+), CD45 (-), CD $73(+)$, CD90 (+), and CD $105(+)$. A total of $22.5 \times 10^{6}$ cells were obtained and contributed in $\alpha$ MEM on $1 \mathrm{cc}$ syringes containing $1.0 \times 10^{6}$ cells for use. All tissue harvesting procedure, cell isolation, culture, and characterizations were conducted in the Tissue and Cell Bank of Dr. Soetomo General Hospital Surabaya, sample-numbered with 120. E/MSC/Penelitian/AdiposeTasijo_09/060220 and was declared suitable for the application. This study has been accepted by the Ethics Committee with the research number 014-KEP-UB-2020.

\section{Testicular Torsion Model of Wistar Rat}

Twenty-two male Wistar rats ( $\mathrm{n}=5$ /group and 2 rats for the negative control group) weighing $250-300$ gr were separated into 5 groups. All operations were performed under sterile conditions. The rats were put under anesthesia via an intraperitoneal route using $75 \mathrm{mg} / \mathrm{kg}$ ketamine and $15 \mathrm{mg} / \mathrm{kg}$ xylazine. All of the processes were done by 1 operator. A mid scrotal incision was made to gain access to the testicle. Testicular torsion model was simulated by twisting the left testicle for $720^{\circ}$ counterclockwise. The testicle was then fixed in a torsion position for 3 hours by fixating the 


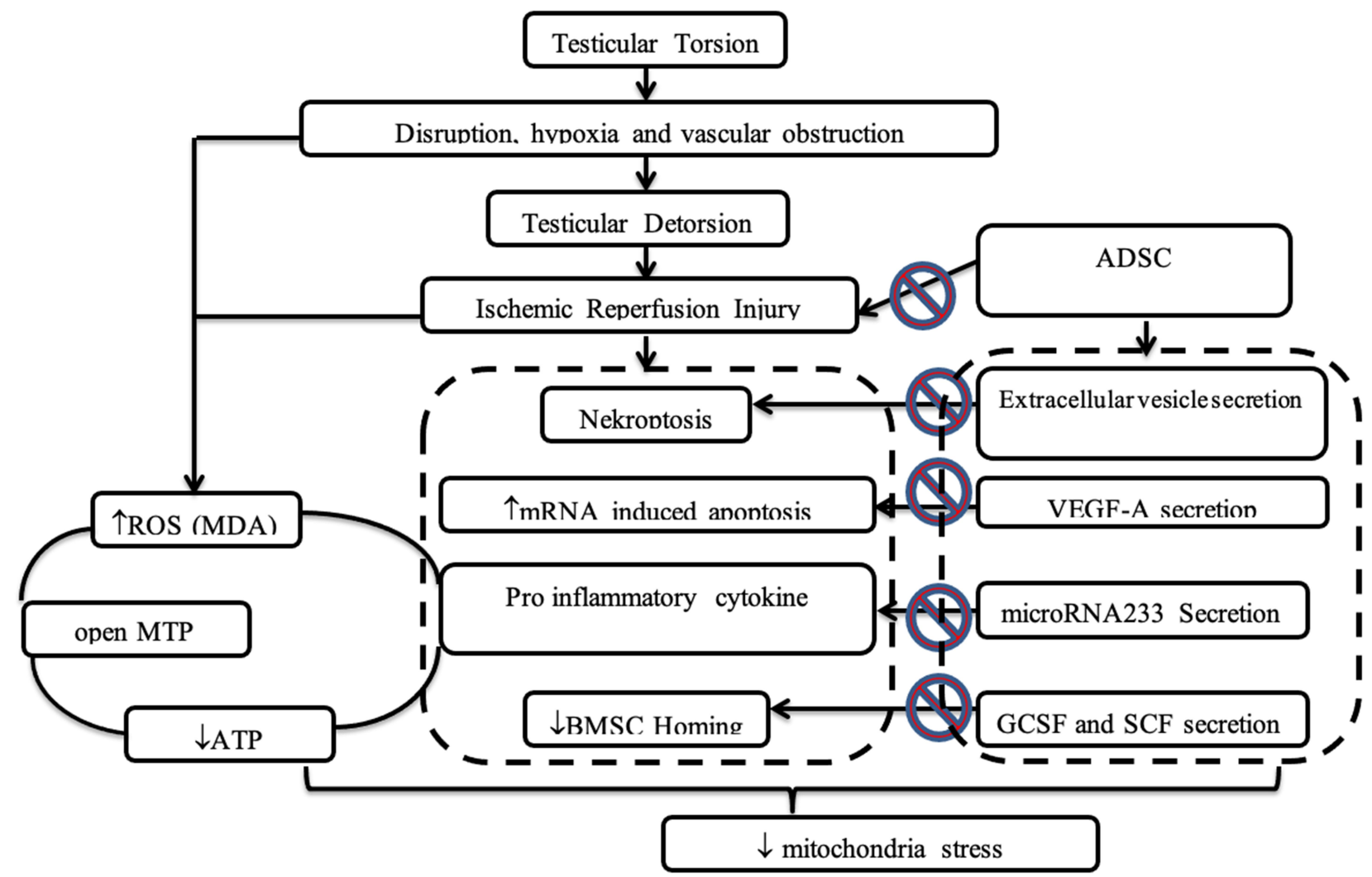

$\downarrow_{\text {oxidative }}$ stress. $\downarrow_{\text {ROS }} . \downarrow_{\text {apaoptosis }}$ and cell death. $\downarrow_{\text {pro-inflammatory } \text { cytokine. } \uparrow \text { NaDPH oksidase }}$

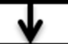

$\downarrow_{\text {MDA }}$

Figure I Research flow of the study.

testicle capsule to the scrotal wall using an atraumatic 4-0 silk suture. The rats were kept under sedation using ketamine, and the explored testicle part was protected using sterile moist gauze and warm light for 3 hours. Based on Cosentino et al, 1986, the process of histological ischemia and reduction of fertility would begin in 3 hours after the $720^{\circ}$ twisting of the testicle. ${ }^{9}$ (Figure 2).

Each of the two groups consisted of 5 male Wistar rats with testicular torsion model without hADSC therapy (Group I). Testicular detorsion was done in 3 hours after testicular torsion. This group were then given intratesticular $1 \mathrm{cc}$ of saline injection 30 minutes after testicular detorsion. There were 2 other groups, each consists of 5 male Wistar rats with testicular torsion model with hADSC therapy (Group II). Testicular detorsion was done in 3 hours after the testicular torsion. This group was then given intratesticular human ADSC injection $\left(1 \times 10^{6}\right.$ cells in $1000 \mu \mathrm{L}$ PBL solution) into the rete testis around 30 minutes after testicular detorsion. These animals were euthanized after 1 week and 4 weeks according to their respective groups, which followed by orchidectomy. After the orchidectomy, about 1 gram of testicular tissue was extracted for the homogenization process with $9 \mathrm{~mL}$ of PBS solution to clean off the blood cells. The sample was then reserved at $4^{\circ} \mathrm{C}$ for subsequent MDA level measurement using the ELISA method and histopathological examination using Johnsen score assessment. The last group consists of 2 rats without any treatment or model (negative control group). Enzyme-linked immunosorbent assay (ELISA) measurements were done using ELISA (FineTest ${ }^{\circledR}$ Rat Coll ELISA kit range 7.813-500ng/mL).

All animal models of this study were housed in solid plastic cages with four rats on each cage. Cleaning of the cages was done daily, and the temperature was kept at $26-29^{\circ} \mathrm{C}$. The animals were fed with standard rodent chow and given water ad libitum. The temperature was monitored every morning using a thermometer. The cage was left open under the sun every morning between $8-10$ 

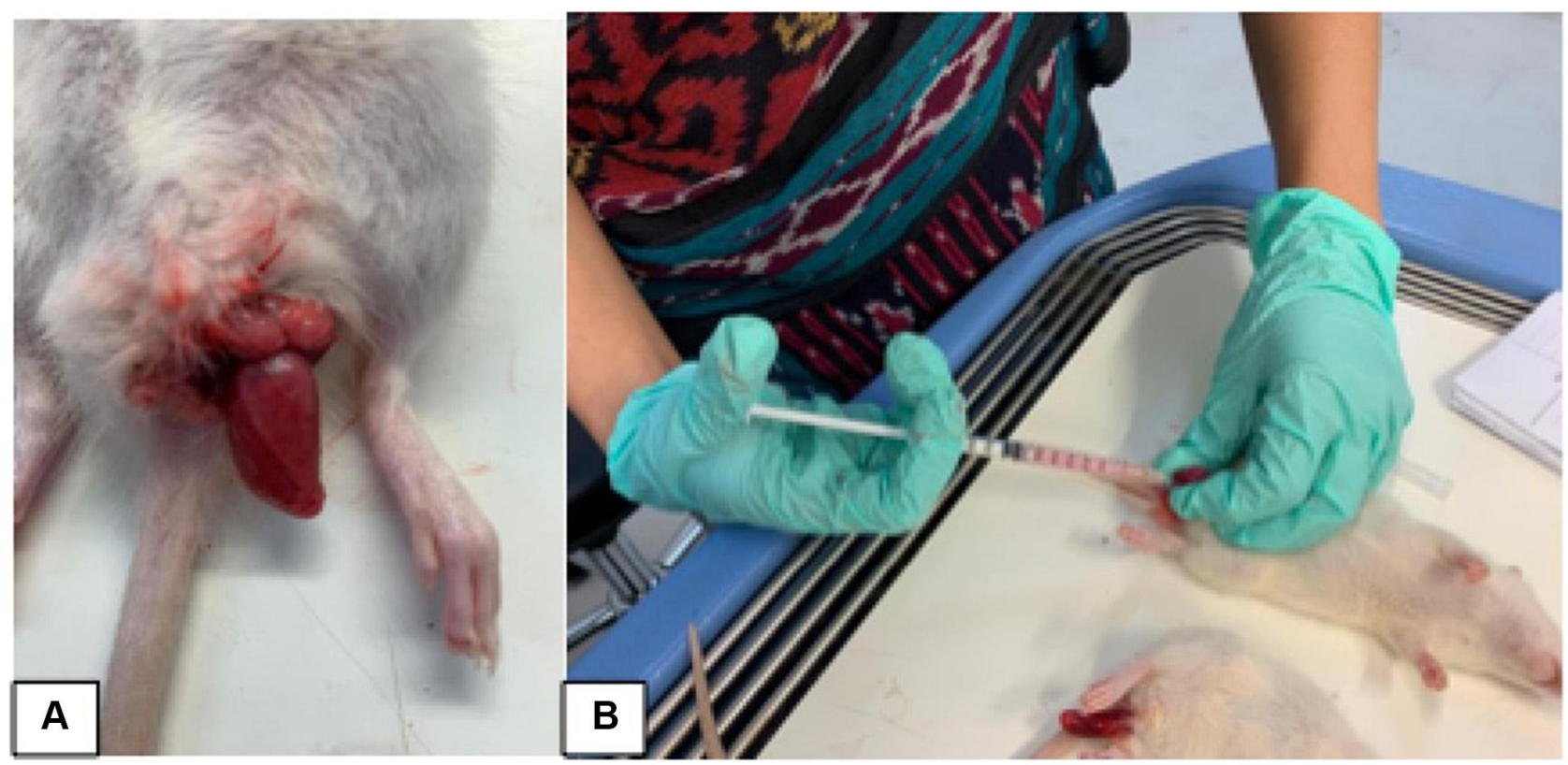

Figure 2 Testicular torsion model was simulated by twisting the left testicle for $720^{\circ}$ counterclockwise (A), Intratesticular human ADSC injection (IxI0 ${ }^{6}$ cells in $1000 \mu \mathrm{L}$ $\mathrm{PBL}$ solution) into the rete testis (Icc) (B).

AM, during the cleaning process. The study was conducted in the Biochemical and Bioscience Laboratory of Brawijaya University Malang and had received ethical clearance from the ethical committee. All objects of the study had received treatments as per the animal welfare guideline, according to William Russel and Rex Burch. ${ }^{10}$ For the statistical analysis, values are expressed as mean \pm $\mathrm{SD}(\mathrm{ng} / \mathrm{mL})$. Groups were compared with the one way ANOVA. The values of $p<0.05$ were considered statistically significant. The SPSS version 21.0 was used for the statistical analysis.

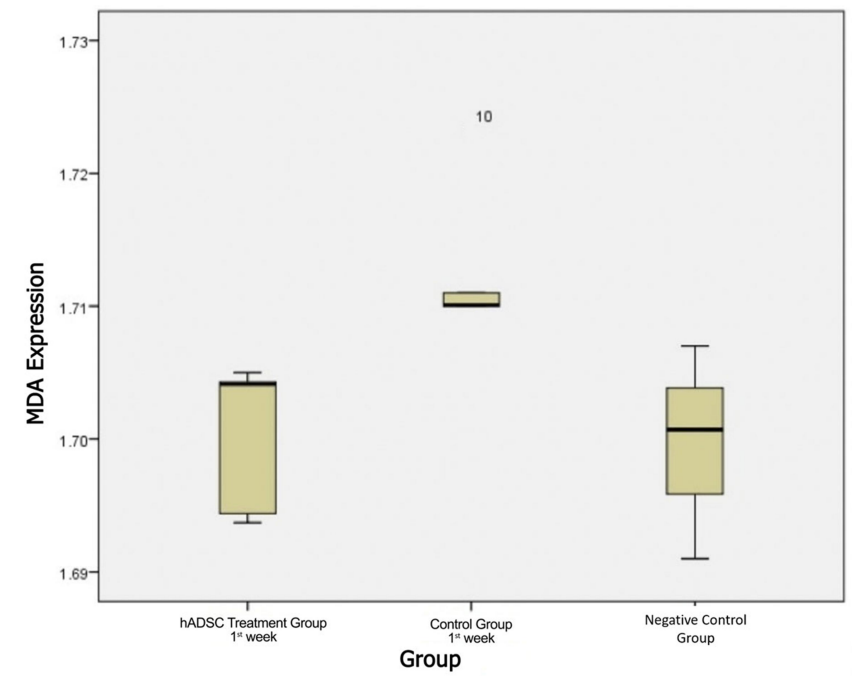

\section{Result of the Study MDA Concentration}

The result of MDA examination using the ELISA method has shown a concentration difference between group I (groups without therapy), group II (hADSC therapy), and negative control group (healthy mice) (Figure 3). MDA concentration was higher in group I during 1st and 4th week of observation. MDA concentration in healthy mice (group III) was $1.6996 \pm 0.008 \mathrm{ng} / \mathrm{mL}$, which used as baseline. Statistical analysis using one-way ANOVA compared

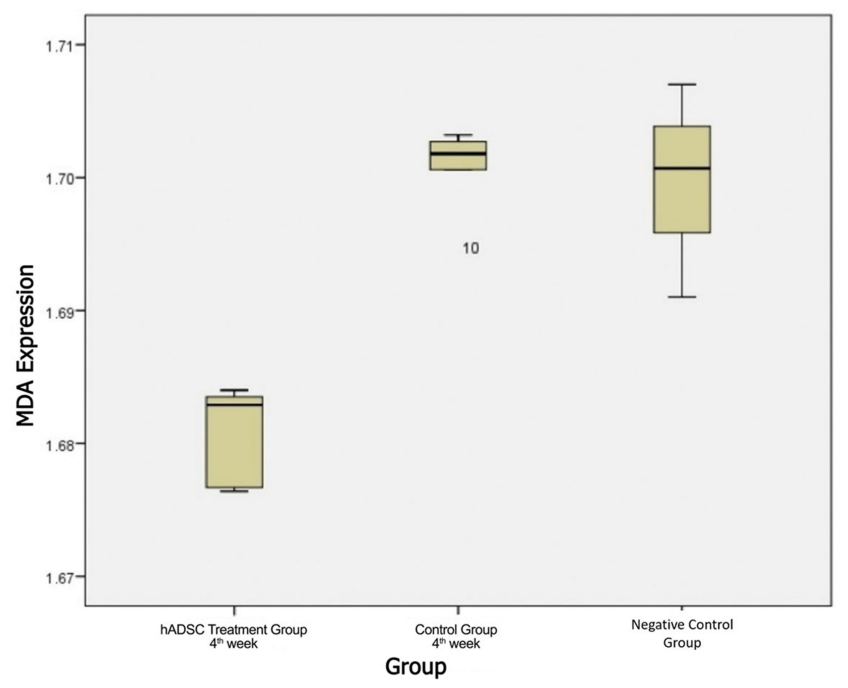

Figure 3 MDA expression level, Ist week and 4th week of observation. 
Table I Comparison of MDA Concentration

\begin{tabular}{|c|c|c|c|c|c|}
\hline & $\begin{array}{l}\text { Negative Control Mean } \\
(\mathrm{ng} / \mathrm{mL})\end{array}$ & $\begin{array}{l}\text { Group I (Torsion/Detorsion) } \\
\text { Mean (ng/mL) }\end{array}$ & $\begin{array}{l}\text { Group II (T/D+Treatment Group) } \\
\text { Mean }(\mathrm{ng} / \mathrm{mL})\end{array}$ & $\mathbf{F}$ & Sig \\
\hline I week & $1.6996 \pm 0.008$ & $1.7129 \pm 0.0058$ & $1.7003 \pm 0.0057$ & 23.343 & 0.000 \\
\hline 4 week & $1.6996 \pm 0.008$ & $1.7004 \pm 0.0039$ & $1.6807 \pm 0.0038$ & 6.412 & 0.016 \\
\hline
\end{tabular}

group I, group II, and negative control group shown significant different in both $1 \mathrm{st}$ and 4th week $(\mathrm{F}(2.10)=223.343$, $\mathrm{p}=0.000$ and $\mathrm{F}(2.10)=6.412, \mathrm{p}=0.016)$. (Table 1)

For 1st week after therapy, MDA concentration for group I was $1.7128 \pm 0.0058 \mathrm{ng} / \mathrm{mL}$ which was significantly higher than group II which was $1.7003 \pm 0.0057 \mathrm{ng} / \mathrm{mL}$ $(\mathrm{p}=0.025)$. Post hoc analysis between group II and negative control group showed that MDA concentration was higher but not statistically significant $(\mathrm{p}=0.986)$ (Table 2$)$.

At the 4th week after therapy, MDA concentration for group I was $1.7004 \pm 0.00387 \mathrm{ng} / \mathrm{mL}$ which also significantly higher than group II which was $1.6807 \pm 0.00381 \mathrm{ng} / \mathrm{mL}$ $(p=0.000)$. Post hoc analysis showed no statistically different between therapy and healthy group $(p=0.972)$ (Table 2$)$.

\section{Histological Examination}

Differences of Johnsen scores between group I and group II were shown in Figure 4. It could be interpreted that the increase in Johnson's score occurred in both groups, but the increase in the score of hADSC therapy group was higher than the control group at the 4th week of observation.

In Table 3, Johnsen score between group I and group II was statistically different at 1 st week and 4th week. Post hoc analysis showed that there was no significant different between group I and II during 1st week observation $(\mathrm{p}=0.703)$. After 4 weeks, group II that was injected

Table 2 Post Hoc Analysis for MDA Concentration

\begin{tabular}{|l|l|l|l|l|}
\hline Week & \multicolumn{2}{|l|}{ Group } & Mean Difference & Sig. \\
\hline Ist & I & Negative Control & 0.0133 & 0.039 \\
& & II & 0.0126 & 0.025 \\
& II & Negative Control & 0.0073 & 0.986 \\
& & I & -0.0126 & 0.025 \\
\hline \multirow{2}{*}{ 4th } & \multirow{2}{*}{ I } & Negative Control & 0.0008 & 0.001 \\
& & II & 0.0197 & 0.000 \\
& II & Negative Control & $-\mathbf{0 . 0 1 8 9}$ & $\mathbf{0 . 9 7 2 *}$ \\
& & I & -0.0197 & 0.000 \\
\hline
\end{tabular}

Note: *There was no difference on MDA concentration between group II and negative control group.
hADSC showed greater improvement which had statistically different score than group without hADSC $(\mathrm{p}=0.044)$. We also compared the Johnsen score between the treatment group and negative control group which was healthy mice and showed there was no statistically significant between them $(\mathrm{p}=0.195)$. This result showed that the group that were injected with hADSC had almost similar results with healthy group (negative control group) (Table 4). Histological comparison (Figure 5) showed the testicular histology was significantly better in group II (with hADSC) than group I.

\section{Discussion}

Disruption of the blood vessel and arterial obstruction due to testicular torsion can cause tissue hypoxia. ${ }^{5,11}$ Post-detorsion reperfusion in testicular torsion will cause inflammation and trigger oxidative stress, which generates ROS. ROSproduces toxic substances that cause damage to the DNA, lipid peroxidation in the cellular and mitochondrial membrane, and damage to the testicular tissue. ${ }^{4,5} \mathrm{MDA}$ is an organic compound formed from ROS with the formula of $\mathrm{CH} 2(\mathrm{CHO}) 2$. In some organs, stem cell administration on the damaged organ is essential in preventing cellular damage and death through the necroptosis prevention process, reducing messenger ribonucleic acid (mRNA), which triggers apoptosis and preventing oxidative stress. ${ }^{12}$ This study aimed to learn about the effect of ADSC administration on an ischemia-reperfusion injury that is caused by testicular torsion in the Wistar rat model by using MDA level measurement that is produced by the oxidative stress process.

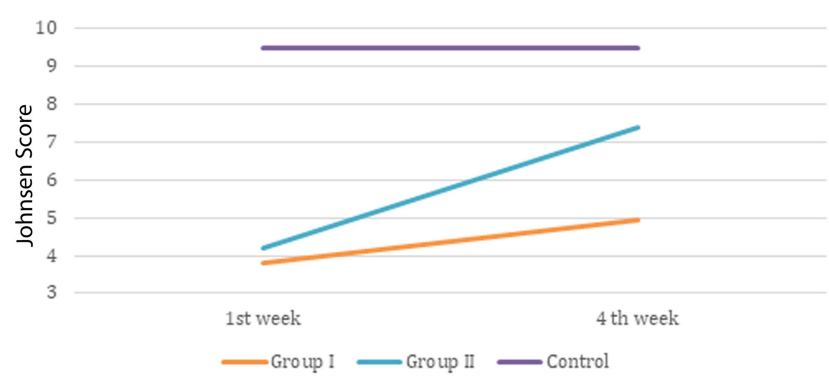

Figure 4 Johnsen score comparison between groups during Ist and 4th week. 
Table 3 Comparison of Johnsen Score Examination

\begin{tabular}{|l|l|l|l|l|}
\hline Observation & $\begin{array}{l}\text { Negative Control } \\
\text { Johnsen Score }\end{array}$ & $\begin{array}{l}\text { Group I (Torsion/Detorsion) } \\
\text { Johnsen Score }\end{array}$ & $\begin{array}{l}\text { Group II (T/D+Treatment Group) } \\
\text { Johnsen Score }\end{array}$ & F \\
\hline Ist week & $9.47 \pm 0.092$ & $3.82 \pm 0.753$ & $4.22 \pm 0.921$ & 39.578 \\
4th week & $9.47 \pm 0.092$ & $4.932 \pm 0.823$ & $7.365 \pm 1.709$ & 0.000 \\
\end{tabular}

Table 4 Post Hoc Analysis Johnsen Score

\begin{tabular}{|l|l|l|l|l|}
\hline Week & \multicolumn{2}{|l|}{ Group } & Mean Difference & Sig. \\
\hline I & I & Negative Control & -5.65 & 0.000 \\
& & II & -0.45 & 0.703 \\
& \multirow{2}{*}{ II } & Negative Control & -5.2 & 0.000 \\
& & I & 0.45 & 0.703 \\
\hline \multirow{2}{*}{4} & \multirow{2}{*}{ I } & Negative Control & -4.53 & 0.010 \\
& & II & -2.43 & 0.044 \\
& \multirow{2}{*}{ II } & Negative Control & $-\mathbf{2 . 1}$ & $\mathbf{0 . 1 9 5}$ \\
& & I & 2.43 & 0.044 \\
\hline
\end{tabular}

Note: *There was no difference on Johnsen Score between group II and negative control group.

This study was conducted in vivo on an experimental animal, which is a Wistar rat. Wistar rat was chosen for this study because of the testicular structural similarities to that of humans. ${ }^{13}$ In this study, we found that the hADSC therapy group's MDA level was reduced over time compared to the control group, at both week-1 and week-4. This finding shows that hADSC therapy can reduce the severity of ischemiareperfusion injury shown by the reduction of the MDA levels in the treatment group. This finding is similar to that of Yuan et al in 2017, which stated that stem cell therapy could reduce the risk of ischemia-reperfusion injury in the renal through the

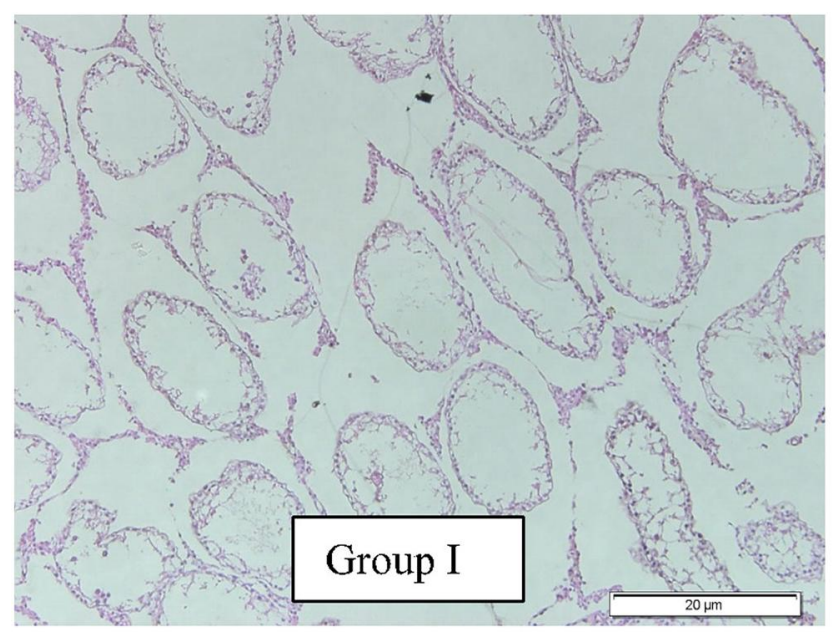

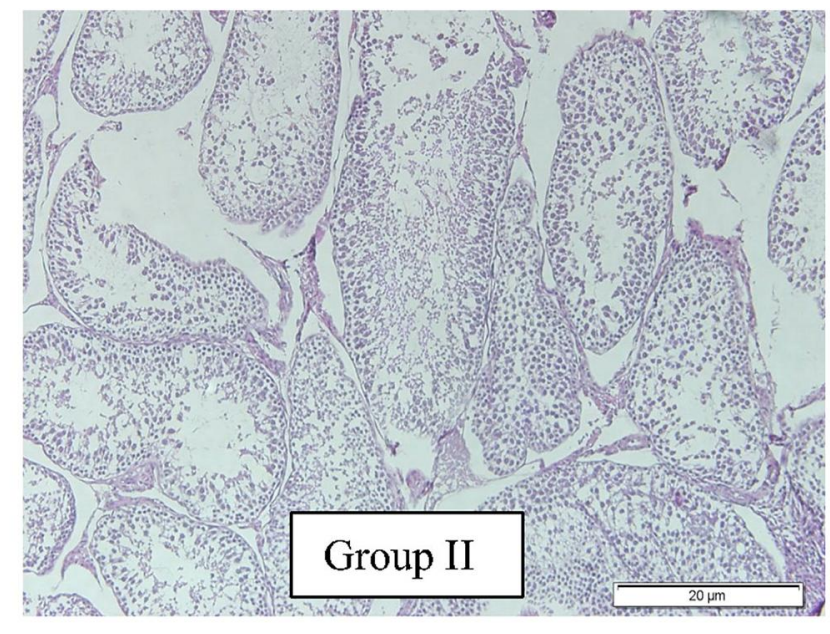

inhibition of necroptosis event. Extracellular vesicles released by stem cells can prevent necroptosis through SP1 protein inside the renal cell, which is the ligand for the cell's growth and endurance. ${ }^{14}$ Other studies by Bi et al in 2015 and Lin et al in 2003 described that stem cell therapy could trigger bone marrow stem cell mobilization to the injured cell. This can lead to an increased cellular growth factor expression, thus triggering cell regeneration in the renal tubules after the ischemiareperfusion injury. ${ }^{15,16}$ Furthermore, Zhuo et al in 2017 showed that stem cell administration into the renal could restore the balance between the existing antioxidant and oxidant inside the ischemic renal. ${ }^{17}$

In this study, stem cell therapy was able to prevent and restore cell damage that was caused by ischemia-reperfusion injury. Stem cells in other organs, i.e., the brain or heart, are able to restore the post-injury impairment of cellular structure and function that was triggered by ischemic stress. However, the effect of stem cell therapy on testicular torsion is still yet to be known. In some other organs, a stem cell has the ability to differentiate into various cell types, such as endothelial, neuronal, and glial cells, therefore allowing the restoration of tissue revascularization and perfusion. Moreover, the stem cell can also trigger the secretion of growth factor and exosome, which serves to maintain and restore cardiomyocyte cell, neuronal

Figure 5 Histopatological comparison between group I and II.

Figure 5 Histopatological comparison between group I and II. 
cell, and stromal tissue. This process can prevent further damage caused by ischemia-reperfusion injuries, such as apoptosis that could cause long term tissue damage and induce fibrotic tissue. Stem cell injection can also trigger the mobilization of marrow stem cells to the injured area, therefore stimulating the restoration of the already injured tissue. ${ }^{18}$ Some mechanisms mentioned above have shown that stem cells can reduce post-ischemia-reperfusion injuries and tissue damage caused by oxidative stress, which was marked by the reduction of MDA levels, the excess production of its oxidative stress process.

ADSC therapy can integrate into the interstitial and seminiferous tubule regions, as well as the walls of the testicular blood vessels, secrete various growth factors (for example, bFGF and SCF), reduce oxidative stress, regulate hormone levels, and then promote regeneration of Leydig cells and germ cells, thereby contributing on the improvement of histological appearance and Johnsen's score in the testes. According to a study conducted by Haahr et al the safety and effect of ADSC therapy for testicular functional recovery have been confirmed in a variety of clinical practices. ${ }^{19}$

The effect of stem cell administration on the testicle is not yet known to be exact. In this study, the administration of human ADSC was able to reduce cellular damage caused by post-ischemia reperfusion injury oxidative stress marked by the reduction of the MDA levels. The ADSC stem cell is a type of stem cell that is able to differentiate into a steroidogenic cell. Therefore, ADSC has the potential to differentiate into a germinal cell. ADSC also has a role in germinal cell proliferation, cell migration, cell adhesion, and anti-apoptotic factor inside the testicle. ${ }^{20,21}$ It is suspected that these features provide protective effects against cell and tissue damages after an ischemiareperfusion injury.

There are some limitations in our study, one of which is no standardized intra-organ ADSC dosage. Some existing studies showed various ADSC dosages, which are measured based on the total of cells. Moreover, the most optimal source of stem cells, the composition of stem cells, cell dosage, and administration method (intravascular or intra-organ) is still controversial to date. ${ }^{22}$ In this study, the human ADSC dosage used was $1 \times 10^{6}$ cells in $1000 \mu \mathrm{L}$ PBL solution into the rete testis (about $1 \times 10^{6}$ cells $(1 \mathrm{cc})$ ) via intratesticular route. ${ }^{23}$ The administration of intratesticular human ADSC is based on the presence of confounding blood-testis-barrier (BTB), which could complicate the action of ADSC if given as an intravascular injection. This finding is also supported by Shinohara et al in 2018, which proved that direct stem cell intratesticular injection into the seminiferous tubule of an infertile rat is a significant route of administration. After the intratesticular injection, the stem cell will adhere to Sertoli cell, and migrate through the BTB among Sertoli cell, and proliferate in the basal membrane subsequently. ${ }^{24}$

\section{Conclusion}

Intratesticular hADSC administration can inhibit ROS formation due to ischemia-reperfusion injury in testicular tissue after testicular detorsion in Wistar rats. The use of stem cell injection therapy in cases of ischemia-reperfusion injury is one of the promising therapeutic alternatives in the future, considering how destructive the result of ischemia-reperfusion injury can be in various organs. Further studies about the characteristics of the used stem cell, stem cell dosage, and route of administration are still required to optimize the therapeutic effect of stem cell use for restoring cellular and tissue damage that is caused by ischemic stress.

\section{Disclosure}

The authors report no conflicts of interest for this work.

\section{References}

1. Mellick LB. Torsion of the testicle: it is time to stop tossing the dice. Pediatr Emerg Care. 2012;28(1):80-86.

2. Ta A, D'Arcy FT, Hoag N, D'Arcy JP, Lawrentschuk N. Testicular torsion and the acute scrotum: current emergency management. Eur $J$ Emerg Med. 2016;23(3):160-165.

3. Gordhan CG, Sadeghi-Nejad H. Scrotal pain: evaluation and management. Korean J Urol. 2015;56(1):3-11.

4. Sharp VJ, Kieran K, Arlen AM. Testicular torsion: diagnosis, evaluation, and management. Am Fam Physician. 2013;88(12):835-840.

5. Ergur BU, Kiray M, Pekcetin C, Bagriyanik HA, Erbil G. Protective effect of erythropoietin pretreatment in testicular ischemia-reperfusion injury in rats. $J$ Pediatr Surg. 2008;43 (4):722-728.

6. Arena S, Iacona R, Antonuccio P, et al. Medical perspective in testicular ischemia-reperfusion injury (Review). Exp Ther Med. 2017;13(5):2115-2122.

7. Parlaktas BS, Atilgan D, Ozyurt H, et al. The biochemical effects of ischemia-reperfusion injury in the ipsilateral and contralateral testes of rats and the protective role of melatonin. Asian J Androl. 2014;16 (2):314-318.

8. Volarevic V, Nurkovic J, Arsenijevic N, Stojkovic M. Concise review: therapeutic potential of mesenchymal stem cells for the treatment of acute liver failure and cirrhosis. Stem Cells. 2014;32(11):2818-2823.

9. Cosentino MJ, Nishida M, Rabinowitz R, Cockett AT. Histopathology of prepubertal rat testes subjected to various durations of spermatic cord torsion. $J$ Androl. 1986;7(1):23-31.

10. Russell WMS, Burch RL. The Prin - Ciples of Humane Experimental Technique. London, UK: Methuen; 1959:238.

11. Fehér ÁM, Bajory Z. A review of main controversial aspects of acute testicular torsion. $J$ Acute Dis. 2016;5(1):1-8.

12. Codina M, Elser J, Margulies KB. Current status of stem cell therapy in heart failure. Curr Cardiol Rep. 2010;12(3):199-208. 
13. Mikuz G. Testicular torsion: simple grading for histological evaluation of tissue damage. Appl Pathol. 1985;3(3):134-139.

14. Yuan X, Li D, Chen X, et al. Extracellular vesicles from human-induced pluripotent stem cell-derived mesenchymal stromal cells (hiPSC-MSCs) protect against renal ischemia/reperfusion injury via delivering specificity protein (SP1) and transcriptional activating of sphingosine kinase 1 and inhibiting necroptosis. Cell Death Dis. 2017;8(12):3200.

15. Lin F, Cordes K, Li L, et al. Hematopoietic stem cells contribute to the regeneration of renal tubules after renal ischemia-reperfusion injury in mice. J Am Soc Nephrol. 2003;14(5):1188-1199.

16. Bi L, Hou R, Yang D, et al. Effect of bone marrow stem cell mobilisation on the expression levels of cellular growth factors in a rat model of acute tubular necrosis. Exp Ther Med. 2015;10(2):618-624.

17. Zhuo W, Liao L, Xu T, Wu W, Yang S, Tan J. Mesenchymal stem cells ameliorate ischemia-reperfusion-induced renal dysfunction by improving the antioxidant/oxidant balance in the ischemic kidney. Urol Int. 2011;86(2):191-196.

18. Barzegar M, Kaur G, Gavins FNE, Wang Y, Boyer CJ, Alexander JS. Potential therapeutic roles of stem cells in ischemia-reperfusion injury. Stem Cell Res. 2019;37:18.

19. Haahr MK, Jensen CH, Toyserkani NM, et al. Safety and potential effect of a single intracavernous injection of autologous adipose-derived regenerative cells in patients with erectile dysfunction following radical prostatectomy: an open-label phase I clinical trial. EBioMedicine. 2016;5:204-210.
20. Yazawa T, Mizutani T, Yamada K, et al. Differentiation of adult stem cells derived from bone marrow stroma into Leydig or adrenocortical cells. Endocrinology. 2006;147:4104-4111.

21. Hosseinzadeh Shirzeily M, Pasbakhsh P, Amidi F, Mehrannia K, Sobhani A. Comparison of differentiation potential of male mouse adipose tissue and bone marrow derived-mesenchymal stem cells into germ cells. Iran J Reprod Med. 2013;11:965-976.

22. Kroger N, Nagler A. Controversies in stem cell transplantation and cellular therapies (COSTEM): introduction by the co-chairpersons of the COSTEM congress. Leukemia Suppl. 2012;1(Suppl 1):S1.

23. Meligy FY, Abo Elgheed AT, Alghareeb SM. Therapeutic effect of adipose-derived mesenchymal stem cells on Cisplatin induced testicular damage in adult male albino rat. Ultrastruct Pathol. 2019;43 (1):28-55.

24. Shinohara MK, Morimoto H, Watanabe S, Shinohara K. Reversible inhibition of the blood testis barrier protein improves stem cell homing in mouse testes. $J$ Reprod Dev. 2018;64(6):511-522.

\section{Publish your work in this journal}

Research and Reports in Urology is an international, peer-reviewed, open access journal publishing original research, reports, editorials, reviews and commentaries on all aspects of adult and pediatric urology in the clinic and laboratory including the following topics: Pathology, pathophysiology of urological disease; Investigation and treatment of urological disease; Pharmacology of drugs used for the treatment of urological disease. The manuscript management system is completely online and includes a very quick and fair peer-review system, which is all easy to use. Visit http://www.dovepress.com/ testimonials.php to read real quotes from published authors. 